\title{
GESTAÇÃO INDÍGENA AKWẼ XERENTE
}

Carmelita Curtidi Xerente Orientadora de Estudo

Noemi Waktadi Xerente
Professora Alfabetizadora

Vanda Brudi Xerente

Professora Pesquisadora

\section{RESUMO}

A gravidez da mulher akwẽ é muito desejada, principalmente se nascer um filho do sexo masculino, as duas famílias ficam muito contentes. Durante a gestação, quem mais cuida da mulher grávida é a mãe dela, repassando-lhe todos os ensinamentos que ela precisa saber para cuidar bem do filho que vai nascer. Tudo o que a mulher grávida desejar comer durante a gravidez, ela deve comer para evitar que seu filho nasça com algum tipo de problema ou até mesmo que a mulher sofra um aborto; e durante a gravidez da mulher, o marido também deve fazer resguardo.

PALAVRAS-CHAVE: gestação. cuidados com a grávida; resguardo.

\section{ROWASKUKTURÊ}

Tô dadki wamre za aiktepre tpkẽzanĩ. Akwẽ kra za zeparkwai dkikrê wam re pkẽzanĩ kmã snã ktra tanẽmẽ nõkwam nõrĩ wasãwa zatô pkẽ tôisnã kra zo nmĩpar tô pikõi dkikrê wamre za aiktepre tsa zatô ku dure tkrê dawapar nõkwa ktmã mrmẽ mõnõ wa, tanẽnmẽ pikõ wasã pari dasa tekmẽsikõdi Kãtô siwakru zawre kru mõrkdi. Zatô aimõ ĩtdekwai nõrĩ nhanẽ romkmãdâ pikõ wasã re krĩ hêmba mõnõ tkrê wasku tazi zatô waihkusnã nõkwa mnõrĩ krhemba.

PALAVRAS-CHAVE: pikõi wasã; dawasã mã krda nĩpsê mnõze. 
A gestação da mulher Akwẽ Xerente sempre é bem vinda, principalmente quando nasce uma criança do sexo masculino. A família do rapaz fica contente e também a família da mulher, porque, quando a mulher começa ter filhos, multiplicam a família e o partido clânico da pintura corporal. Isso significa que a pintura corporal dos filhos acompanha a pintura do pai.

$\mathrm{Na}$ gestação da pikõ (mulher), às vezes muda até o comportamento do seu jeito com seu companheiro, e na primeira gestação a mãe fica muito preocupada com sua filha. Por isso ela começa a orientar psicologicamente para ficar preparada até na hora do parto como, por exemplo, como receber a criança, não respirar muito somente espirando devagar. Os seios dela aumentam, alguns delas engordam, com algumas não acontece isso. Na primeira gravidez começa adquirir os conhecimentos da maternidade, como cuidar da criança, da alimentação e da educação da criança e também ela enjoa do marido e também de alguns alimentos. A mãe da gestante Akwẽ sempre está cuidando da sua filha, toda vez que fica grávida, não importa a idade da mulher (pikõ).

Para a ciência do povo Akwẽ, a pessoa do sexo feminino é mais organizada desde sua formação no ventre materno. A gestação é caracterizada visualmente pela presença da barriga bem arredondada e marcada pela linha negra ser menos acentuada do que na gestação de um sexo masculino. Isso nos leva a entender que na ciência $A k w \tilde{e}$ essas característica marcam a organização da mulher.

No período da gestação da mulher Akwẽ ninguém deve negar qualquer coisa se ela pedir, e deve oferecer mesmo que ela não peça. Âs vezes se ela desejar algo, é isso, pode levar em aborto ou a criança pode nascer com deficiência física como, por exemplo, nasce com boca torta ou fica babando, e também precisa se alimentar bem, fazer física, trabalhar em serviços de maneira que isso leve a criança a nascer saudável e não engorde dentro do ventre da mãe. A gestante não deve tomar susto durante a gravidez. Se isso acontecer, pode levar a um aborto, segundo a professora Noemi Waktadi. A mulher grávida não deve ficar na porta de casa ou no portão ou voltar do meio do caminho ou olhar para trás. Se acontecer isso leva a demora do nascimento na hora do parto.

As parteiras devem estar preparadas com seus medicamentos 
Akwẽ para a criança nascer mais rápido. Por exemplo, semente de abóbora, semente de melancia e outros como preparar e pisar a semente de abóbora ou semente de melancia, misturar com um copo de água e tomar de uma vez.

Quando a mulher Akwẽ engravida, o marido dela é considerado como a grávida. Por isso, se ele for caçar e pescar, se vir algo por acaso vai fazer mal à criança. Quando a criança nascer como, por exemplo, encontrar um sucuri jibóia. A criança começa a chorar a partir de um mês de nascimento, na mesma hora que ele viu algo e as crianças podem ficar com sequela, podem ficar paralíticas ou pode até levá-las à morte. 